GHÂNCARAN: JURNAL PENDIDIKAN
BAHASA DAN SASTRA INDONESIA
$\begin{gathered}\text { http:///ejournal.iainmadura.ac.id/ghancaran } \\ \text { E-ISSN : 2715-9132; P-ISSN: 2714-8955 } \\ \text { Dol 10.19105/ghancaran.v2i2.3912 }\end{gathered}$

\title{
Ragam Pertanyaan dan Teknik Bertanya Pengajar BIPA dalam Interaksi Pembelajaran di Kelas
}

\author{
Gamal Kusuma Zamahsari*, Agus Purnomo Ahmad Putikadyanto**, \\ Redhitya Wempi Ansori*** \\ ${ }^{*}$ Communication Science Department, Faculty of Economics \& Communication, Bina \\ Nusantara University, Malang Campus \\ **IAIN Madura, Pamekasan \\ ***Universitas Nahdlatul Ulama Blitar
}

Alamat surel: gamal.zamahsari@binus.edu; aguspurnomo@iainmadura.ac.id

\begin{tabular}{l}
\hline \hline \\
\hline Kata Kunci: \\
Ragam pertanyaan; \\
Teknik Bertanya; \\
Pengajar \\
BIPA
\end{tabular}

\section{Abstrak}

Penelitian ini bertujuan mendeskripsikan ragam pertanyaan dan teknik bertanya pengajar BIPA dalam pembelajaran di kelas. Pendekatan dan desain penelitian ini adalah kualitatif. Hasil penelitian menunjukkan bahwa pengajar BIPA cenderung menuturkan ragam pertanyaan yang berupa pertanyaan referensial, pertanyaan pancingan, pertanyaan klarifikasi, pertanyaan konfirmasi, dan pertanyaan pemahaman. Aspek-aspek teknik bertanya yang baik dalam pembelajaran yaitu menjaga pemelajar tetap fokus pada proses tanya jawab, menyusun pertanyaan dengan sangat baik, menyediakan waktu tunggu, memberikan umpan balik yang positif, dan memeriksa jawaban untuk diperbaiki telah dilakukan oleh pengajar.

\begin{tabular}{ll}
\hline \hline & Abstract \\
\hline Keywords: & This study aims to describe the types of question and question \\
Type of Question; & techniques of BIPA teachers in classroom learning. The approach \\
Question Technique; & and design of this research is qualitative. The results showed that \\
BIPA teacher. & BIPA teachers tended to speak a variety of questions in the form of \\
& referential questions, reqruitment questions, clarification questions, \\
& confirmation questions, and understanding questions. The aspects \\
& of good questioning techniques in learning, namely keeping \\
& learners focused on the question and answer process, structuring \\
questions very well, providing waiting time, providing positive \\
feedback, and checking answers for improvement have been done \\
by the teacher.
\end{tabular}

\section{PENDAHULUAN}

Perlu dipahami bahwa dalam pembelajaran Bahasa Indonesia bagi penutur asing (BIPA), pengajar selain berperan sebagai sutradara juga berperan sebagai aktor. Pengajar juga dipandang sebagai ujung tombak untuk mencapai keberhasilan sebuah tujuan pembelajaran (Susanto, 2007). Interaksi dalam kegiatan pembelajaran harus dibangun dengan baik supaya tujuan pembelajaran dapat tercapai dan pemelajar merasa senang dengan pemahaman yang telah mereka dapatkan. Pengajar dapat membangun interaksi dalam kegiatan pembelajaran dengan mengajukan pertanyaan. 
Seorang pengajar tentu tidak serta merta bertanya tanpa arah dan tujuan yang jelas karena pengajar bahasa Indonesia bagi penutur asing (BIPA) mengemban tugas memberikan pemahaman tentang bahasa dan budaya Indonesia kepada pembelajar BIPA. Pengajar juga memiliki peran penting dalam kegiatan komunikasi di kelas. Pengajar menyampaikan materi pelajaran kepada pembelajar dan pembelajar menerima serta belajar melalui pesan-pesan itu. Mengajar adalah tentang membangun hubungan komunikasi yang efektif dan afektif dengan para pemelajar. Pengajar yang efektif adalah komunikator yang efektif (Wrench, 2020). Mengajar adalah tentang cara membangun hubungan komunikasi dengan pembelajar (Tafonao, 2018; Kurtz, 2017). Bahasa yang dituturkan pengajar di kelas tentu berbeda dengan tuturan profesi lain, apalagi tuturan yang digunakan pengajar Bahasa Indonesia Bagi Penutur Asing (BIPA).

Penelitian terdahulu mengenai pertanyaan pengajar di kelas bahasa asing pernah dilakukan tentang strategi bertanya guru bahasa Inggris di salah satu Madrasah di Palembang, Sumatera Selatan (Astrid et al., 2019). Hasil penelitian tersebut menyatakan guru menggunakan tiga jenis strategi bertanya yaitu konvergen, divergen, dan prosedural. Strategi bertanya yang paling dominan adalah konvergen (ya/tidak dan jawaban singkat. Ketiganya didukung dengan alasan dari guru berdasarkan pemahaman siswa, menarik perhatian siswa, meningkatkan pemikiran siswa di tingkat yang lebih tinggi, dan melibatkan siswa dalam kegiatan pembelajaran. Strategi yang digunakan guru dalam penelitian tersebut dapat diartikan sebagai upaya modifikasi percakapan dengan menggunakan pertanyaan ya/tidak dan jawaban singkat. Namun, pertanyaan ya/tidak yang terlalu dominan akan mengurangi esensi percakapan seperti di lingkungan nyata bahasa tersebut digunakan. Sebab, pada dasarnya bahasa digunakan untuk berkomunikasi. Bahasa dimulai sebagai tuturan sosial dalam bentuk dialog. Pernyataan tersebut didukung pendapat dari penelitian terdahulu selanjutnya yang menyatakan bahwa unit dasar bahasa adalah interaksi percakapan bukan struktur kalimat atau bentuk gramatikal (Walqui, 2006). Begitu pula dalam kelas BIPA, tentu yang dilakukan bagaimana menggunakan bahasa target yang dipelajari untuk berkomunikasi. Ketika pengajar berkomunikasi dengan para pembelajar di kelas, pengajar akan banyak melakukan bermacam-macam pemodifikasian struktural terhadap tugas yang diberikan kepada pelajarnya atau pada tingkat kemampuan pembelajar yang diajarnya (Suyitno, 2004).

Berdasarkan teori modifikasi percakapan yaitu interaksi termodifikasi adalah hasil yang muncul dari kegiatan percakapan berupa permintaan klarifikasi atau pengulangan, konfirmasi, atau cek pemahaman (Pica, 1985). Hasil penelitian teori modifikasi pertanyaan tersebut digunakan sebagai landasan penelitian ini karena relevan dengan teori-teori Walqui (2006) \& Suyitno (2014) dan menambahkan dari Astrid et al (2019). Sementara itu, teori teknik bertanya diambil dari hasil penelitian yang menyatakan ada lima teknik bertanya efektif dalam pembelajaran di antaranya, menjaga pemelajar tetap fokus pada proses tanya jawab, menyusun pertanyaan dengan sangat baik, menyediakan waktu tunggu, memberikan umpan balik yang positif, dan memeriksa jawaban untuk diperbaiki (Gall \& Rhody, 1987). Berdasarkan landasan pemikiran tersebut penelitian ini bertujuan mendeskripsikan ragam pertanyaan dan teknik bertanya pengajar BIPA dalam pembelajaran di kelas. Harapan dari hasil penelitian ini dapat memberikan gambaran kepada calon pengajar BIPA tentang cara mengawal interaksi pembelajaran di kelas mereka dengan baik.

\section{METODE}

Penelitian ragam pertanyaan dan teknik bertanya pengajar BIPA dalam interaksi pembelajaran di kelas ini menggunakan desain penelitian kualitatif. Pemilihan jenis penelitian ini berdasarkan dua pertimbangan. Pertama, penelitian ini bersifat induktif 
yang menyimpulkan hasil penelitian dengan data yang tersedia. Kedua, penelitian ini bersifat deskriptif yang berusaha mendeskripsikan secara akurat dan sistematis antara data dengan teori. Sumber data penelitian adalah pengajar BIPA di kelas pemula khususnya di level BIPA 2 sesuai SKL BIPA yang disusun Kemdikbud. Lokasi penelitian dilakukan di program Bunga BIPA ISP MCE. Pengajar BIPA sudah berpengalaman mengajar BIPA minimal selama lima tahun. Data penelitian ini berupa data verbal tuturan pertanyaan pengajar BIPA. Aspek nonverbal yang menyertai tuturan pengajar BIPA selama proses pembelajaran di kelas tidak dijadikan fokus penelitian. Pada artikel ini hanya disajikan data dari satu rangkaian pertemuan untuk mempermudah penjelasan keterkaitan antar ragam dan teknik bertanya yang digunakan pengajar. Data verbal tuturan pengajar BIPA dalam kegiatan pembelajaran di kelas ditranskrip dan dipilahpilah susuai indikator ragam pertanyaan dan teknik bertanya. Analisis data didukung hasil observasi di kelas dan teori yang relevan. Data disajikan dalam rangkaian percakapan untuk menunjukkan proses interaksi antara pengajar dan pemelajar BIPA.

\section{HASIL DAN PEMBAHASAN}

Hasil penelitian ditemukan lima ragam petanyaan dan teknik bertanya pengajar BIPA dalam pembelajaran di kelas. Ragam pertanyaan yang muncul di antaranya yaitu (1) pertanyaan referensial, (2) pertanyaan pancingan, (3) permintaan klarifikasi, (4) cek konfirmasi, dan (5) cek pemahaman dalam tuturan pertanyaan pengajar BIPA. Teknik bertanya yang digunakan pengajar menunjukkan kelima teknik efektif (1) menjaga pemelajar tetap fokus saat tanya jawab, (2) menyusun pertanyaan dengan sangat baik, (3) menyediakan waktu tunggu, (4) memberikan umpan balik yang positif, dan (5) memeriksa jawaban untuk diperbaiki.

\section{Ragam pertanyaan referensial dan teknik bertanya pengajar BIPA}

Pertanyaan referensial merupakan pertanyaan yang biasa digunakan dalam kehidupan sehari-hari dalam komunikasi. Penutur mengajukan pertanyaan kepada mitra tuturnya karena ingin tahu dan belum mengetahui jawaban yang akan diperolehnya. Cullen (1998: 181) memberikan penjelasan bahwa penggunaan pertanyaan referensial terjadi ketika pengajar bertanya sesuatu kepada para pembelajar misalnya, "Apa yang kalian lakukan ketika di waktu senggang?" yang jawabannya murni tidak diketahui pengajar, karena murni memiliki tujuan komunikasi.

\begin{tabular}{ll}
\hline Pengajar & Bagaimana kabar keluarga kos? \\
\hline Pemelajar & Baik. \\
\hline Konteks & $\begin{array}{l}\text { Pengajar BIPA membuka pelajaran dengan } \\
\text { bertanya kabar pembelajar dan aktivitasnya }\end{array}$ \\
\hline
\end{tabular}

Tabel 1. Pertanyaan Referensial

Motif pengajar mengajukan pertanyaan referensial tidak serta merta hanya bertujuan untuk membangun komunikasi biasa saja. Jika dilihat dari teori teknik bertanya efektif dalam pembelajaran (Gall \& Rhody, 1987), pertanyaan pengajar pada kutipan data tersebut bertujuan untuk menjaga pemelajar agar tetap fokus pada topik tanya jawab yang sesuai dengan topik pembelajaran pada hari itu. Pertanyaan disusun dengan baik seusai jalur untuk mencapai tujuan pembelajaran. Artinya, pengajar memperhatikan teknik bertanya yang efektif. Pertanyaan dalam pengaturan pendidikan dibagi menjadi dua jenis sesuai dengan tujuan pertanyaan: display dan referensial (Walsh, 2013). Pertanyaan referensial berbeda dengan pertanyaan display (misalnya, pertanyaan pemahaman pada sebuah bacaan) di mana pengajar sudah mengetahui jawabannya dan pengajar hanya bertanya sehingga para pembelajar dapat menyampaikan pemahaman atau pengetahuannya (Cullen, 1998). 
Pertanyaan pengajar pada data tersebut dipilih karena dapat membangun interaksi di awal kelas. Oleh sebab itu, dipilihlah ragam pertanyaan referensial untuk membuka percakapan guna menciptakan interaksi di kelas daripada langsung menggunakan pertanyaan display. Di sisi lain, pilihan ragam pertanyaan referensial atau display yang layak digunakan di kelas. Penelitiannya mempelajari perilaku guru bahasa Inggris di kelas untuk lebih memahami bagaimana merancang pertanyaan yang dapat membantu pengembangan pengetahuan dan mendorong munculnya pemikiran kreatif. Partisipan yang terlibat dalam penelitian ini adalah tiga guru (laki-laki dan dua perempuan) dari kebangsaan yang berbeda, mengajar di sekolah menengah umum di Uni Emirat Arab. Studi tersebut menemukan bahwa jumlah pertanyaan referensial yang diajukan lebih sedikit daripada tampilan pertanyaan. Studi ini juga menunjukkan bahwa pertanyaan display paling sering digunakan sebagai pemanasan kelas kegiatan, untuk meninjau pelajaran sebelumnya dan memperoleh informasi faktual. Namun, respon siswa lebih lama diperoleh menggunakan pertanyaan referensial (Qashoa, 2013).

Peneliti berpendapat bahwa ragam pertanyaan referensial dan display semuanya memiliki peran penting dan layak digunakan dalam pembelajaran. Namun, perlu diingat Kembali pelevelan dalam pembelajaran BIPA. Tidak bisa seorang pengajar dalam level pemula misalnya, serta merta mengajukan pertanyaan display terus menerus. Pemelajar pada level pemula masih memiliki pemahaman yang terbatas, artinya memerlukan bimbingan dari pengajar untuk mencapai pemahan daripada sekadar dijejali pertanyaan yang sifatnya display atau menguji pemahaman. Interaksi komunikasi yang dapat membangun situasi tutur akan terhambat khususnya di kelas pemula, jika pengajar hanya bertanya dengan tujuan menguji pemahaman tanpa mendesain dan menyusun urutan pertanyaan sesuai level pemelajar.

\section{Ragam Pertanyaan Pancingan (Recruitment) dan Teknik Bertanya Pengajar BIPA}

Pertanyaan pancingan berfungsi memancing perhatian pembelajar dan menumbuhkan minatnya untuk fokus terhadap materi yang dipelajari. Recruitment digunakan untuk menarik perhatian pembelajar dan menumbuhkan minat mereka terhadap tugas yang diberikan (Hall J. K., 2001). Berikut data yang menunjukkan bentuk pancingan dalam pembelajaran BIPA di kelas.

\begin{tabular}{ll}
\hline Pengajar & Aktivitas di keluarga kos. Kemarin PR ya? \\
\hline Pemelajar & lya. \\
\hline Konteks & $\begin{array}{l}\text { Pengajar berusaha menarik perhatian pembelajar } \\
\text { supaya kembali fokus pada PRnya }\end{array}$ \\
\hline
\end{tabular}

Tabel 2. Pertanyaan Pancingan

Data pertanyaan pancingan masih berkaitan dengan percakapan sebelumnya pada data pertanyaan referensial. Terlihat pertanyaan yang diajukan pengajar sudah didesain dan dipersiapkan dengan sangat baik. Sesuai dengan teknik bertanya yang efektif dalam pembelajaran (Gall \& Rhody, 1987). Pengajar berusaha menjaga pemelajar tetap fokus dan mendesain pertanyaan dengan sangat baik. Pesan yang dapat diambil dari data tersebut adalah seorang pengajar yang baik harus menyiapkan rencana pembelajaran bahkan sampai pada level memilih ragam pertanyaan dan menjaga teknik bertanya yang sesuai.

\section{Ragam Pertanyaan Klarifikasi dan Teknik Bertanya Pengajar BIPA}

Permintaan klarifikasi dalam tuturan pertanyaan pengajar BIPA berbentuk (1) pertanyaan sederhana, (2) pertanyaan $5 \mathrm{~W}$ (apa, siapa, kapan, di mana, dan 
bagaimana), dan (3) pertanyaan berintonasi naik. Permintaan klarifikasi (clarification request) adalah tindakan salah satu penutur meminta bantuan kepada mitra tutur untuk memahami ucapan mitra tutur sebelumnya melalui pertanyaan (termasuk 5W, ya-tidak, intonasi naik) atau pernyataan seperti saya tidak paham, atau tolong ulangi! (Pica, 1985).

\begin{tabular}{ll}
\hline Pemelajar & $\begin{array}{l}\text { Saya pendek tidur tadi malam, tadi saya belajar di } \\
\text { pagi (berbicara tidak jelas) }\end{array}$ \\
\hline Pengajar & Apa? Belajar tadi pagi? (berbicara pelan) \\
\hline Pemelajar & Ya, Saya belajar tadi pagi. \\
\hline Konteks & $\begin{array}{l}\text { Pengajar bertanya kepada pemelajar tentang } \\
\text { kegiatan sehari-hari }\end{array}$ \\
\hline
\end{tabular}

\section{Tabel 3. Pertanyaan Klarifikasi}

Pertanyaan ini merupakan wujud dari penerapan teknik bertanya efektif dalam pembelajaran (Gall \& Rhody, 1987). Pengajar memberikan umpan balik yang positif sekaligus memeriksa jawaban pemelajar untuk diperbaiki. Dengan adanya umpan balik tersebut memancing adanya interaksi yang baik antara pengajar dan pemelajar. Pengajar BIPA adalah model bahasa bagi pemelajar (Zamahsari, Roffi'uddin, \& Widodo, 2019). Pengajar harus mampu menciptakan suasana penggunaan bahasa yang nyata sesuai lingkungan yang digunakan. Interaksi antara guru dan siswa di ruang kelas adalah salah satu sarana utama untuk belajar di ruang kelas (Hall \& Verplaetse, 2000)

\section{Ragam Pertanyaan Konfirmasi dan Teknik Bertanya Pengajar BIPA}

Pertanyaan konfirmasi (confirmation check) adalah tindakan dari salah satu penutur untuk mengonfirmasi ucapan mitra tutur melalui pengulangan dengan intonasi naik, dari sebagian atau seluruh pesan (tuturan) (Pica, 1985).

\begin{tabular}{ll}
\hline Pengajar & Anda tinggal di mana? \\
\hline Pemelajar & $\begin{array}{l}\text { Saya tinggal di jalan Ma..g..lang (berbicara dengan } \\
\text { pelafalan yang salah) }\end{array}$ \\
\hline Pengajar & Jalan? \\
\hline Pemelajar & Gelang a..Ma-ge-lang \\
\hline Pengajar & Jalan Magelang, oke sip. \\
\hline Konteks & $\begin{array}{l}\text { Pengajar dan pemelajar bercakap-cakap tentang } \\
\text { alamat pemelajar }\end{array}$ \\
\hline
\end{tabular}

Tabel 4. Pertanyaan Konfirmasi

Pertanyaan pada data ini merupakan bagian dari teknik bertanya efektif dalam pembelajaran (Gall \& Rhody, 1987). Pengajar ingin memeriksa jawaban pemelajar untuk diperbaiki melalui kalimat tanya. Ragam konfirmasi yang diutarakan pengajar membuat pemelajar berpikir ulang dan menyadari bahwa yang diucapkannya ternyata salah. Sebagaimana pendapat para peneliti, biasanya, guru mengajukan pertanyaan untuk memancingnya siswa berpikir dan mendorong siswa untuk mengembangkan ide-ide mereka (Lemke, 1990).

\section{Ragam Pertanyaan Pemahaman dan Teknik Bertanya Pengajar BIPA}

Pertanyaan pemahaman (comprehenshion check) adalah tindakan dari salah satu penutur berusaha untuk menentukan apakah mitra tutur telah memahami pesan yang baru disampaikan (Pica, 1985). 


\begin{tabular}{ll}
\hline Pemelajar 1 & Dia. Bu P tetapi sudah nenek \\
\hline Pengajar & Nenek \\
\hline Pemelajar 2 & Nenek, kakak? \\
\hline Pengajar & $\begin{array}{l}\text { Kakek... Nenek, kakek, bapak, ibu. Kita sudah } \\
\text { berbicara itu hari Senin atau Selasa. }\end{array}$ \\
\hline Pemelajar 2 & Oke. \\
\hline Pengajar & Jadi, siapa Bu P? \\
\hline Pemelajar 2 & Mbak J nenek kos. \\
\hline Pengajar & Nenek kos Mbak J \\
\hline Pemelajar 2 & lya. Nenek kos Mbak J \\
\hline Konteks & Pengajar dan pemelajar bercakap-cakap tentang \\
& PR keluarga kos \\
\hline
\end{tabular}

\section{Tabel 5. Pertanyaan Pemahaman}

Keterampilan komunikasi lisan dibangun bertahap melalui tanya jawab antara pengajar dan pembelajar dalam kelas kecil dan intensif (Richards, 2001). Tanya jawab tersebut bertujuan membangun sebuah interaksi percakapan antara pengajar dan pembelajar. Ragam pertanyaan pengajar BIPA yang dituturkan di dalam kelas memicu sebuah interaksi. Interaksi pengajar dan pembelajar dapat meningkatkan kemampuan berbahasa dan menggunakan bahasa yang telah dipelajari (Yuqin, 2010). Di sisi lain, berdasarkan prinsip Vigotsky bahwa interaksi sosial adalah basis dari pembelajaran dan pengembangan. Belajar adalah sebuah proses dan internalisasi yakni kemampuan dan pengetahuan dibentuk dari ranah sosial ke dalam bidang kognitif (Walqui, 2006). (Harmer, 2017) menegaskan bahwa pengajar harus mendorong peserta didik untuk berkomunikasi dan meminimalisasi keterlibatannya dalam percakapan tersebut. Artinya, pengajar sebaiknya hanya sebagai fasilitator yang memancing munculnya produksi Bahasa dari pemelajar.

Bahasa sebagai alat komunikasi (belajar bahasa) adalah belajar menggunakan bahasa target yang dipelajari (Bilotserkoveks \& Gubina, 2019). Oleh karena itu, ke lima bentuk pertanyaan tersebut muncul ketika pengajar BIPA menyampaikan materi pembelajaran melalui sebuah topik yang diadaptasi dari kehidupan sosial yang terjadi di lingkungan sosial sebenarnya. Pertanyaan yang dituturkan bukan lagi pertanyaan display semata melainkan pertanyaan yang memiliki tujuan komunikasi.

Kajian mengenai interaksi pembelajaran Bahasa asing khususnya BIPA dengan kondisi pengajar asli orang Indonesia dan pemelajar berasal dari negara lain, memberikan khasanah kajian yang menarik. Karakteristik pertanyaan yang dituturkan pengajar dinyatakan berpengaruh terhadap interaksi belajar mengajar di kelas (AlZahrani \& Al-Bargi, 2017).

\section{SIMPULAN}

Pengajar BIPA tidak boleh serta merta menggunakan pertanyaan secara asal dalam pembelajaran di kelas. Pertanyaan yang digunakan dalam interaksi pembelajaran memiliki muatan pembelajaran yang sesuai dengan topik dan materi pembelajaran. Pertanyaan pengajar BIPA juga memiliki fungsi membantu dan mengontrol fokus pembelajar terhadap materi pembelajaran yang harus dikuasainya. Oleh sebab itu, saran bagi para pengajar BIPA untuk membuat persiapan yang matang mengenai rencana pembelajaran yang akan dipakai. Bukan hanya sekadar RPP, tetapi juga memperhatikan alur skenario pembelajaran dan memilih ragam instruksi pembelajaran yang baik demi keberhasilan pemelajar.

Pertanyaan yang muncul bukan lagi pertanyaan yang sebatas memiliki tujuan komunikasi saja, melainkan pertanyaan yang membantu pemelajar tetap fokus pada tujuan pembelajaran. Pertanyaan yang diujarkan pengajar harus dipersiapkan dan 
didesain dengan sangat baik sesuai level pemelajar. Misalnya, seorang pengajar tidak mungkin bertanya dengan maksud menguji pemahaman yang sangat rumit kepada pemelajar level pemula. Pemilihan level kata dalam menyampaikan instruksi pembelajaran penting diperhatikan. Perlu digaris bawahi, pembelajaran BIPA bukan sekadar menguji pemahaman pemelajar melainkan membangun interaksi dan membangun pemahaman pemelajar supaya bisa menggunakan bahasa Indonesia dengan baik dan benar.

Pembelajaran BIPA adalah pembelajaran yang memberikan pemahaman tentang penggunaan bahasa sebagai alat komunikasi. Komunikasi yang dibangun dari interaksi antara pengajar dan pemelajar di dalam kelas dapat melatih kemampuan komunikasi pembelajar BIPA. Pertanyaan yang disiapkan dengan baik dan diujarkan menggunakan prinsip-prinsip dari teknik bertanya yang baik memberikan hasil yang positif bagi pemelajar. Pada intinya sebuah pembelajaran harus memiliki scenario yang matang. Skenario pembelajaran adalah salah satu kunci keberhasilan pemelajar mencapai apa yang mereka pelajari.

Peneliti selanjutnya dapat menggali lebih dalam lagi mengenai penggunaan kalimat tanya dalam pembelajaran. Selain ragam dan teknik, peneliti dapat memfokuskan pada pembahasan efek dari pilihan ragam pertanyaan terhadap respon pemelajar dalam interaksi pembelajaran. Peneliti juga dapat memperluas cakupan penelitian mengenai interaksi pembelajaran BIPA, bahasa guru BIPA, dan lain sebagainya dengan menggunakan pisau bedah keilmuan lainnya.

\section{DAFTAR RUJUKAN}

Astrid, A., Amrina, R. D., Desvitasari, D., Fitriani, U., \& Shahab, A. (2019). The Power of Questioning: Teacher's Questioning Strategies in the EFL Classrooms. Indonesian Research Journal in Education /IRJE/, 3(1), 91-106. https://doi.org/10.22437/irje.v3i1.6601

Al-Zahrani, M., \& Al-Bargi, A. (2017). The Impact of Teacher Questioning on Creating Interaction in EFL:. English Language Teaching, 10(6), 135-150. doi:10.5539/elt.v10n6p135

Bilotserkovets, M., \& Gubina, O. (2019). Target Language Teaching by Means of ELearning: A Case Study. Romanian Journal for Multidimensional Education / Revista Romaneasca pentru Educatie Multidimensionala, 11(4), 17-29.

Cullen, R. (1998). Teacher Talk and The Classrom Context. ELT Journal Oxford University, 52(3).

Gall, M. D., \& Rhody, T. (1987). Review of Research on Questioning Techniques. In W. W. Willen, Question, Questioning Techniques, and Effective Teaching (p. 30). National Education Association US.

Hall, J. K. (2001). Methods for Teaching Foreign Languages. Merrill Prentice-Hall.

Hall, J. K., \& Verplaetse, L. S. (2000). Second and Foreign Language Learning Through Classroom Interaction. Lawrence Erlbaum Associates, Publishers.

Harmer, J. (2017). The Practice of English Language Teaching 4th Edition. Pearson Longman.

Kurtz, S. M. (2017). Learner-centred communication training. Oxford textbook for communication in oncology and palliative care. Oxford University Press.

Lemke, J. L. (1990). Talking science: Language, learning, and values. ERIC.

Pica, T. D. (1985). Making Input Comprehensible: Do Interactional Modifications Help? TESOL Sumer Meeting, Georgetown University. Georgetown University.

Qashoa, S. H. (2013). Effects of teacher question types and syntactic structures on EFL classroom interaction. The International Journal of Social Sciences, 7(1), 52-62. 
Richards, J. \&. (2001). Approaches and Methods in Language Teaching. Cambridge University Press.

Susanto, G. (2007). Kompetensi dan Profesionalisme Pengajar BIPA Ditinjau dari Sudut Pandang Pebelajar BIPA. Semiloka dan Konferensi Internasional BIPA. Jakarta.

Suyitno, I. (2004). Pengetahuan Dasar BIPA Pandangan Teoritis Belajar Bahasa. Grafika Indah.

Tafonao, T. (2018). Peranan Media Pembelajaran dalam Meningkatkan Minat Belajar Mahasiswa. Jurnal Komunikasi Pendidikan, 2(2), 103-114.

Walqui, A. (2006). Scaffolding Instruction for English Language Learners: A Conceptual Framework. International Journal of Bilingual Education and Bilingualism, 9(2), 159-180.

Walsh, S. (2013). Classroom discourse and teacher development. Edinburgh University Press.

Wrench, S. J. (2020). Communication, Affect, \& Learning in the Classroom 4rd Edition. Creative Commons.

Yuqin, Z. \&. (2010). A Study of Teacher Talk in Interaction in English Classes. Chinese Journal of Applied Linguistics, 33(2).

Zamahsari, G. K., Roffi'uddin, A. H., \& Widodo, H. S. (2019). Implementasi Scaffolding dalam Pembelajaran BIPA di Kelas Pemula. Jurnal Pendidikan: Teori, Penelitian, dan Pengembangan, 4(1), 68-78. 